\title{
Taking matters into their own hands: An analysis of the determinants of state-conducted peacekeeping in civil wars
}

\author{
Nicolas Rost \\ Department of Politics and Management, University of Konstanz \& United Nations \\ Office for the Coordination of Humanitarian Affairs for Somalia (OCHA) \\ J Michael Greig \\ Department of Political Science, University of North Texas
}

\begin{abstract}
Why and when do states take the burden upon themselves to send peacekeepers into a civil war, rather than relying on intergovernmental organizations to do so? While there are a few empirical studies on the conditions under which the UN sends peacekeeping missions, no such analyses of state-conducted peacekeeping exist. In this study, a theoretical framework on state-conducted peacekeeping in civil wars is developed and empirically tested. Not surprisingly, when acting outside international organizations, states are able to take their own interests directly into account and select those civil wars to which they send peacekeepers accordingly. States' interests play a much greater role here than, for example, the interests of the major powers do for UN peacekeeping. When states send peacekeepers they are more likely to choose former colonies, military allies, trade partners, or countries with which they have ethnic ties. Yet, this does not mean that state-conducted peacekeeping occurs only where states see their own interests. Contrary to conventional wisdom, states also provide peacekeeping to 'tough' cases, the most challenging civil wars. These are long, ethnic wars. This tendency for states to provide peacekeeping holds when civil wars produce dire effects on civilians. States are more likely to send peacekeepers into civil wars that kill or displace many people. Finally, states react to opportunities: the more previous mediation attempts, the higher the chances for state-conducted peacekeeping.
\end{abstract}

\section{Keywords}

civil war, conflict management, conflict resolution, peacekeeping, United Nations

\section{Introduction}

We've got to recognise that the multilateral system does have its limits. And there have been occasions, I'm afraid, when the UN has been unable to deal with crises in Rwanda, in Kosovo, quite a long list of missed opportunities by the UN. And the case of the Solomons, it would just be too difficult to get the UN to solve this problem. We'll have to do it ourselves, with a coalition of other countries. (Australian Foreign Minister Alexander Downer on the need for Australia to lead a peacekeeping mission to the Solomon Islands, cited in Ponzio, 2005: 178)

During the 1990s, Australia, New Zealand, Fiji, Vanuatu, and Tonga on three occasions sent peacekeeping forces to Papua New Guinea. On Bougainville, an island in the east of the country rich in mineral resources, the Bougainville Revolutionary Army was fighting for independence. The first intervention, in 1994, lasted only three weeks and did not succeed in bringing about peace. During 1997-2003, the same countries sent two further missions to supervise a ceasefire, which succeeded in brokering an agreement. Nigeria sent its own peacekeepers in 1964-1965 to the Katanga region in the Democratic Republic of Congo, and in 
1979 to Chad. These state-led peacekeeping missions suggest an interesting question: Why do individual states, given the frequency of peacekeeping by international organizations such as the United Nations or African Union, bear the costs and provide the public good of peacekeeping to some civil wars?

The United Nations' mandate is to 'maintain international peace and security', and to that end 'to take effective collective measures for the prevention and removal of threats to the peace' (UN Charter, Chapter I, Article 1). In fulfilling this mandate, the UN Security Council, under Chapter VI or VII of the Charter, may decide to send a peacekeeping mission to a conflict area, and the Council has increasingly made use of this power since the end of the Cold War. Some regional intergovernmental organizations are based on similar principles. It makes sense for states to establish international organizations to provide common goods like peacekeeping. But why would individual states do so directly? In this study, we argue that states provide peacekeeping when they have sufficient interests in the civil-war state, the conflict shows a high level of urgency, and they see an opportunity for success.

Civil wars are among the most dangerous types of conflicts in the international system. Not only do they bring death and destruction to the conflicting parties, they also often inflict considerable harm upon the country's civilians through genocide, forced displacement, and longterm negative consequences for public health. ${ }^{1}$ Because they have a propensity to internationalize themselves, civil wars often represent a broader threat to the international community. Thus, understanding the ways in which civil conflicts can be managed has become increasingly important for both scholars and practitioners.

Only a few published studies provide a first examination of which conflicts attract UN peacekeeping (Doyle \& Sambanis, 2000; Gilligan \& Stedman, 2003; Fortna, 2004b; Mullenbach, 2005). No empirical studies of the conditions under which state-conducted peacekeeping missions occur exist to our knowledge. Because of the possibility for selection bias, this omission is important to studies of civil-war peacekeeping. Identifying the conditions under which any type of peacekeeping occurs is as important as understanding when such efforts will be successful. For instance, Sambanis \& SchulhoferWohl (2005) find that UN peacekeeping has been more

\footnotetext{
${ }^{1}$ See Krain (1997) and Harff (2003) on genocides, Schmeidl (1997), Davenport, Moore \& Poe (2003), and Moore \& Shellman (2004) on displacement, and Ghobarah, Huth \& Russett (2003) on public health consequences, all partly as a result of civil war.
}

successful in restoring peace than non-UN peacekeeping. Without controlling for selection bias, empirical analyses of the conditions associated with civil-war conflict management success may yield faulty inferences. In addition, understanding when peacekeeping occurs provides a means of comparison with the factors associated with its success, allowing for a better understanding of the links between the two.

In this study, we examine how third-party states or ad-hoc coalitions of states choose the civil wars they provide peacekeeping to, and when they do so. We not only look at peacekeeping from the perspective of the civil-war country but also examine why third-party states decide to send peacekeepers to a specific conflict. Following a discussion of peacekeeping as one of the options that third-party states have to intervene in a civil war, we develop a theoretical framework that ties together four sets of influences on a third-party state's decision about whether to step into the fray: state interests, the urgency for intervention, risks of peacekeeping, and opportunities for success. We test our theoretical framework empirically by pairing civil-war countries with potential providers of peacekeeping. Thus, we look at peacekeeping from both sides: which wars attract peacekeeping, and whether and for which reasons states step in. In this way, our empirical findings may help to inform future studies on the success of peacekeeping by taking into account which conflicts attract peacekeeping and which countries send in peacekeepers for which reason.

\section{State-conducted peacekeeping}

States have a range of options to intervene in civil conflicts, from doing nothing or expressing 'concern' or imposing sanctions, to intervening diplomatically in the hopes of stimulating an agreement between the belligerents or intervening militarily, supporting one side or as a neutral force. Our study concentrates on this end of the spectrum: military peacekeeping. Peacekeeping is an expensive endeavor, representing one of the most costly means of managing a conflict (Mullenbach, 2005; Carment \& Rowlands, 1998). Not only does each peacekeeping mission impart costs upon states in manpower and resources, it also carries with it important reputational and audience costs. When peacekeepers die, political support for their mission at home often wanes quickly. While fielding a peacekeeping mission is expensive, military intervention may be the only strategy likely to manage a conflict successfully. Yet, even when there is a clear need for third-party conflict management efforts, states, as well as international organizations, tend to be 
judicious in their application of it, intervening when the benefits outweigh the costs.

For the purpose of this study, we define stateconducted peacekeeping as the deployment of military personnel by a single state or an ad-hoc coalition of states to a conflict-affected country with the aim of monitoring, keeping or restoring peace, rather than the aim of helping one of the conflict parties to win or prevent its defeat. Our definition of peacekeeping is similar to one that may be used for UN peacekeeping with the difference that it is carried out by states directly. Nonetheless, state peacekeeping may be mandated by a Security Council resolution, as was the case for the International Force for East Timor in 1999-2000, or the Unified Task Force in Somalia in 1992-1993. While a UN mandate may bestow legitimacy upon state-conducted peacekeeping, the costs are still for the state to bear. As we examine peacekeeping during civil wars, we look at deployments to a 'conflict-affected country' rather than, for instance, to a border area between two warring countries.

As was made clear in the definition, we are not interested in one-sided military interventions with the aim of helping one of the warring parties. The distinction can sometimes be tricky. A state may call an intervention peacekeeping but may have ulterior motives. For example, in August 2008 Russia said its soldiers in Georgia were peacekeepers. In other cases, the motives of an intervening state may change over time. For practical reasons, we rely on Mullenbach's and Dixon's TPI dataset (Mullenbach, 2005) to identify the occurrence of peacekeeping. To distinguish peacekeeping from one-sided interventions, the TPI dataset codes six different purposes for peacekeeping missions: maintaining law and order or a buffer zone, monitoring ceasefires or disarmament, protecting or delivering humanitarian assistance, providing security, and 'others'. Peace enforcement missions are classified as peacekeeping as long as they are not onesided military interventions. In their robustness, the state-conducted peacekeeping missions that we study range from an observation mission in Sri Lanka in 1995 by Canada, the Netherlands, and Norway, to the US-led mission 'Uphold Democracy' in Haiti in 1994-1995. We discuss the circumstances under which states are likely to deploy peacekeepers in the next section.

\section{Stepping in: When states provide peacekeeping}

States, like other providers of peacekeeping, discriminate in their deployment. The demand for peacekeeping far outstrips the supply available from the international community. We argue that for states, it is the concatenation of four sets of forces that influence their propensity to deploy peacekeepers to a civil war. First, potential interveners assess their own interests at stake in the conflict, especially the ties they have with the country experiencing violence. Second, the need a conflict demonstrates for intervention, particularly if it causes a humanitarian emergency, should shape the likelihood that states will deploy peacekeepers. Third, states must take into account potential costs and risks when deciding whether to intervene. Finally, we anticipate that states will be most inclined to provide peacekeepers when they see the greatest opportunity for successful conflict management.

\section{The importance of state interests}

Because peacekeeping is costly, states must be strategic in their application of it, choosing to intervene when their interests are most directly at stake and they have the greatest capacity successfully to manage the conflict. While many conflicts may need peacekeeping, most are tangential to the interests of major powers, those states with the greatest capacity to provide peacekeeping, and thus, peacekeepers may never be deployed to these conflicts (Mueller, 2003). Instead, those conflicts that most directly threaten the interests of the most capable states are the most likely to attract state-conducted peacekeeping.

We see the interests that motivate states to deploy peacekeepers to a civil war in two ways. First, security interests provide motivation for a state or collection of states to deploy peacekeepers to a conflict. Second, the linkages between states provide reasons for them to be concerned by what takes place in a country experiencing war. These linkages can reflect social, economic, or political ties between states that can motivate an outside power to deploy peacekeepers to a civil-war state.

The security concerns posed by a civil war tend to be felt most acutely by that country's neighbors. Borders provide opportunities for interaction between states, allowing for the conditions in one state to influence those of its neighbors (Most \& Starr, 1989; Vasquez, 1993, 1995). Hence, states tend not only to be concerned with events occurring among their neighbors but also seek to influence them (Gochman, 1991; Siverson \& Starr, 1992). Although peacekeeping missions are often thought of as a public good, they also reflect a response to the security interests of the intervener. While refugee flows signal a humanitarian emergency in civilwar states, they also pose a burden for the neighboring states that absorb them, taxing their resources and posing a danger that conflict will spill across their borders. 
In addition, a threat to regional stability is another negative effect of a civil war. Quite often, civil-war belligerents fail to observe international borders, permitting fighting to spill across them, risking the internationalization and diffusion of a conflict. Neighboring states may also fear that outside powers will seek to exploit the power vacuum created by a civil-war state, worrying that foreign powers will intervene in the conflict to support one side and gain a regional foothold. As a result, a civil war, by posing a threat to neighboring states, creates a strategic interest for third parties who value regional stability, reinforcing their propensity to provide peacekeeping to manage the conflict. Those states closest to a civil-war state should have a greater willingness to deploy peacekeepers.

In addition to neighboring states, states with important political, social, and economic interests in a civilwar country have clear incentives to intervene militarily to protect those interests (Regan, 1998; Feste, 1992; Morgenthau, 1967). A military alliance with a state in civil war indicates the importance that a third-party state attaches to the security of that state. By stabilizing an ally in conflict, the deployment of peacekeepers not only provides conflict management, but also enables the ally to live up to its treaty obligations in the future.

Other types of linkages play a role as well. Former colonial ties, because they are linkages between states that share a common history, tend to produce a historical interest that encourages a state to provide peacekeepers to its former colony. A colonial relationship often creates a residual bond rooted in continued economic and social linkages. The former colonizer may feel a sense of responsibility for the stability of the former colony, even if only for self-interested reasons, further encouraging peacekeeping. The close relations and shared histories of France and Britain to their former colonies have encouraged both to provide peacekeeping to them. France in 2008 led an EU peacekeeping mission to Chad and the Central African Republic, while Britain has done the same in Zimbabwe.

Beyond the political linkages between states, social linkages, especially ethnic ties, between the peoples of two states can provide motivation for the deployment of peacekeepers. Considerable evidence in the literature points to the tendency of outside ethnic groups to mobilize both support and military interventions in favor of their ethnic kin in other countries in the face of a threat to the group (Austvoll, 2005; Petersen, 2004; Saideman, 1997, 2002; Davis \& Moore, 1997; Gleditsch, 2007). Given this tendency, it makes sense to expect that similar motivations for support of ethnic kin should create enough interest in an ethnically linked civil-war state to provide peacekeepers.

Economic ties constitute another set of interests between people. When a civil war disrupts important trade with other states, those states experience a direct cost from the civil war. Countries with deep trade links with a civil-war country have a greater interest in seeing a peacekeeping intervention, particularly when the war threatens economic production and trade. In sum, this logic suggests the following hypothesis:

Hypothesis 1: Third-party states will be more likely to provide peacekeeping in civil wars in which they have an important interest at stake.

\section{The urgency for intervention}

While the interests of states play an important role in determining whether peacekeeping is provided, we also see such efforts in conflicts with substantial human suffering that challenge few direct interests of third-party states. Genocide, politicide, and refugee flows caused by civil wars can create recognition of a humanitarian emergency among other states that stimulates their willingness to provide peacekeeping. Although neighboring countries that receive refugees from a civil-war state have a direct interest in the conflict, large civilian displacements also signal the need for peacekeeping among states further away by raising awareness of the scope of the humanitarian emergency. This awareness comes not only from policymakers; Jakobsen (1996) points to a 'CNN-effect' in which media coverage of humanitarian emergencies mobilizes pressures on governments to act. Similarly, advocacy groups can play a role in pressuring governments and international organizations to respond to humanitarian crises. As a result, civil wars that result in genocide or high numbers of refugees are more likely to compel states and organizations to manage the conflict, an effect noted by Regan (1998).

Contributing to this push for peacekeeping is the evolution of the relationship between national sovereignty and individual human rights in international law. This evolution has provided a greater sense of legitimacy for interventions in domestic conflicts when human rights are threatened on a large scale (Evans, 2008; Donnelly, 2003; Dowty \& Loescher, 1996; Weil, 2001). Consistent with this reasoning, several studies have linked peacekeeping missions to humanitarian emergencies (Jakobsen, 1996; Gilligan \& Stedman, 2003; Finnemore, 2004; Regan \& Stam, 2000). These peacekeeping missions are driven by a belief that conditions have 
deteriorated so substantially that only military intervention is likely to manage the conflict.

Intense conflicts can also signal a need for peacekeeping. Intense, long-running conflicts produce bitterness between the belligerents that makes diplomatic efforts to manage the conflict more challenging, as the parties are less likely to reconcile (Doyle \& Sambanis, 2000; Fortna, 2004a,b). When conflict has spiraled out of control, non-military options like negotiation or mediation may seem ineffective, requiring the use of peacekeepers to have any hope of managing the conflict successfully (Kressel \& Pruitt, 1989; Bercovitch, Anagnoson \& Wille, 1991; Bercovitch, 1997; Hartzell, Hoddie \& Rothchild, 2001). Gilligan \& Stedman (2003) find that the likelihood of UN peacekeeping increases as the duration and number of battle-deaths in a conflict increase, an effect also noted by Mullenbach (2005). Following this logic, we expect that states will follow a similar pattern, increasing their willingness to deploy peacekeepers to those conflicts that show the greatest need for intervention.

Hypothesis 2: As the urgency of a civil war increases, the likelihood of peacekeeping increases.

\section{The costs and risks of peacekeeping}

Whether they take humanitarian or their own interests into account, states must balance the need for military intervention against the costs and risks. As they mount, the difficulty a conflict presents to military intervention will negatively affect the likelihood of peacekeeping. States tend to avoid providing peacekeeping when conflict conditions threaten to impose unacceptable costs upon the peacekeepers. The risks and costs that undermine the willingness to provide peacekeeping are likely to be particularly pronounced in what are, sadly, the conflicts that most need peacekeeping.

Ethno-religious conflicts, because they tend to be built upon a history of violence, less easily mutable differences and, often, the political exploitation of such differences, are considerably more difficult to manage, compared to conflicts involving political or economic issues (Hartzell, Hoddie \& Rothchild, 2001). Ethnoreligious conflicts are thus particularly challenging to peacekeepers, making third parties less likely to intervene militarily. Andersson (2000) suggests that civil wars in which control over the government is the contested issue are more likely to attract peacekeeping than identitybased conflicts. Similarly, Durch (1993) argues that secessionist conflicts, conflicts that typically center upon ethnic cleavages, are less likely to attract UN peacekeepers. This logic suggests that because of the threat they present, states should also be less likely to deploy peacekeepers to ethnically based civil wars, even though ethnic links may encourage a third-party state to intervene, as noted above.

The number of factions involved in a conflict can also provide a disincentive for the deployment of peacekeepers by states. While conflicts involving many contesting parties pose obstacles for diplomacy, they create even greater difficulties for peacekeeping missions. Governments considering the provision of peacekeepers to a civil war involving many factions fear the possibility of being caught between a large number of conflict lines, risking the possibility that their peacekeeping forces face unacceptable costs. At the same time, as the number of warring factions increases, the likelihood for incongruent positions among the parties and spoilers to a peace process grows. Conflicts with multiple factions may prove so difficult to resolve that states fear that the introduction of peacekeepers will result in a quagmire in which they bear heavy costs in the fighting while producing neither a lasting settlement to the conflict nor an environment conducive to the ultimate withdrawal of the force.

Hypothesis 3: Peacekeeping is less likely when it is expected to be risky and costly, in civil wars that are perceived as complex.

\section{Opportunities for peacekeeping}

States will seek entry points or opportunities to intervene, engaging in a form of 'cherry-picking' by managing conflicts in which they see the greatest chance for success. Mullenbach (2005) finds that peacekeepers are more likely to be deployed following a ceasefire agreement between the parties. In our view, however, talks need not be successful to encourage states to deploy peacekeepers.

Mediation and peacekeeping can be part of the same broader international effort to resolve a conflict. If belligerents accept offers to participate in third-party mediation efforts, they signal to outside states a readiness to settle the conflict, increasing third parties' willingness to provide peacekeepers as a means to build upon the diplomacy. Sustained diplomacy between civil-war belligerents suggests progress that an outside power can seize upon by deploying peacekeepers. The deployment of peacekeepers, as a means with which to back an agreement between the warring sides, can provide the catalyst necessary to produce such a settlement out of a previously unsuccessful peace process. 
Hypothesis 4: Peacekeeping is more likely to take place in civil wars whose conflict parties have agreed to participate in mediation efforts.

\section{Research design}

As we are interested in identifying the conditions under which states provide peacekeeping to ongoing civil wars, we focus our analysis on the population of civil wars identified by Fearon \& Laitin (2003), 1964-1998. ${ }^{2}$ For each year of a civil war, we construct a third-party state/ civil-war state dyad between the country in which the civil war takes place and every state in the international system. ${ }^{3}$ This process produces a dataset of 118,168 dyad-years. After accounting for missing data among the independent variables, our analysis includes 116,036 observations. We conduct further tests in which we analyze separately the influences on peacekeeping by major powers and non-major powers. We report findings for three distinct analyses, one for all dyads, one between all major powers and civil-war states, and one between nonmajor powers and civil-war states. ${ }^{4}$

This dyadic approach allows for a more fine-grained analysis of state-conducted peacekeeping than using civil-war country-years as the unit of analysis, in particular with regard to a third party's interests. Using dyads, we can include links such as military alliances and colonial, ethnic, and trade ties between a civil-war country and every other state. This allows us not only to determine, for example, whether former colonies are more likely to attract peacekeeping, but whether the peacekeeping comes from their former colonizer.

Our dependent variable is the occurrence of peacekeeping by a state or an ad-hoc coalition of states, according to our definition of peacekeeping discussed earlier. To identify the occurrence of peacekeeping, we use Mullenbach's and Dixon's TPI-Intrastate Dispute dataset (Mullenbach, 2005), which codes the occurrence of peacekeeping by states, coalitions of states, and international organizations. Peacekeeping missions in a civil war conducted by states are included in our dependent

\footnotetext{
${ }^{2}$ Our temporal domain begins in 1964 , owing to data limitations on the refugee variable we use for the analysis.

${ }^{3}$ We exclude third-party countries without an army, as well as countries that already provide peacekeepers to a mission by an international organization in the civil-war state.

${ }^{4}$ We also separated contiguous and non-contiguous countries and ran our model separately on these two subsamples. The test for non-contiguous countries showed substantially similar results to those of the overall sample. In the test with contiguous countries, none of the variables was statistically significant.
}

variable, while those stemming from an international organization are excluded. For peacekeeping missions conducted by a coalition of states, each participating state is counted as a provider of peacekeeping. Our rationale for this coding rule is that these multistate peacekeeping missions are 'coalitions of the willing' in which each state makes the choice to participate or not.

Because we are interested in the factors influencing the decision by states to deploy peacekeepers, not the factors that determine the continuation of missions, we only code the peacekeeping variable in the initial year of the intervention (peacekeeping onset). Once a state deploys peacekeepers, we treat the remaining civil-war years for that dyad as outside the risk set for peacekeeping, dropping them from our dataset for the remainder of the war. The subsequent civil-war years are only dropped for a state providing peacekeeping; all other dyad-years remain in the risk set until they too attract peacekeeping or until the civil war ends. As a result, our sample includes 74 incidences of a third-party state sending peacekeepers into a civil war.

In identifying forces that promote sufficient interest by a third-party state in a civil-war country, as described in our theoretical framework above, we look to several factors that create an important linkage between two states. We code a dichotomous variable as 1 if the two states are contiguous, with data from Singer \& Small (1982) generated using EUGene (Bennett \& Stam, 2000). ${ }^{5}$ Using data from Gibler \& Sarkees (2004) generated by EUGene, we code a dichotomous variable describing whether there is a defense pact between the third-party state and the civil-war state. With data from Hensel's (2006) ICOW Colonial History dataset, we identify former colonial relationships. We create two dichotomous ethnic and religious group linkage variables using data from Ellingsen (2000). We code the first variable as 1 if the third-party state shares the same largest ethnic or religious group as the civil-war state (a majority-majority dyad). The second variable is coded as 1 if the largest ethnic or religious group in the thirdparty state is the same as the second largest ethnic or religious group in the civil-war state (a majority-minority dyad). This approach allows us to determine whether it is interest in the ethno-religious majority or minority group that encourages the deployment of peacekeepers.

\footnotetext{
5 Because contiguity perfectly predicts no peacekeeping in our analysis of major powers, we drop from the major power model the contiguity variable and its interaction and exclude the 180 observations of contiguity in the data.
} 
To examine the influence of economic exchanges, we code a variable describing the value of exports and imports of a third-party state with a civil-war state using Gleditsch's (2002) 'Expanded trade and GDP data', version 4.1. Due to its skewness, we use the natural logarithm of the trade variable.

To examine the role that a conflict's urgency plays in peacekeeping, we include four variables. We use the 'forcedflow' variable from Moore \& Shellman's (2004) data on forced displacement, calculating the logarithm of the number of refugees produced by a civil-war state in each year. As neighboring states are most likely to absorb the costs of civil-war refugees, we include an interaction term between the contiguity and refugee variables. We use data from Krain (2005) to create a dichotomous variable for genocide. To measure the intensity of fighting, we use Lacina \& Gleditsch's (2005) dataset, which provides annual data on battle-deaths. We use the natural logarithm of the total number of fatalities produced by the civil war since its onset up to the year in question. To avoid potential endogeneity, we lag each of these three variables by one year. Finally, we include a variable coding the duration of the civil war to date.

We include two variables that reflect the challenge a civil war presents to a third party. We control for the type of conflict using the 'ethwar' variable in Fearon \& Laitin's (2003) dataset, which codes ethnic conflicts as 1 and others as 0 . We also include their variable counting the number of factions involved in the civil war in our model.

An indicator of the opportunity for successful peacekeeping is an ongoing pattern of diplomacy between the belligerents. Owing to the difficulty in observing backchannel negotiations between warring parties, we focus on mediation as our indicator of diplomacy between them. We include a variable measuring the number of mediation efforts the civil-war parties have engaged in to date, lagged by one year, using data from Regan, Frank \& Aydin (2009).

We also include three control variables drawn from the extant literature. Because powerful civil-war states are likely to eschew third-party peacekeeping in their conflicts while strong outside states carry a greater capacity to deploy peacekeepers, we create a measure of the (logged) ratio of the military personnel of the civil-war state to the military personnel of the third-party state. We use the Correlates of War National Material Capabilities Data Set 3.02 (Singer, Bremer \& Stuckey, 1972) for data on military personnel. As major powers have a greater capacity to deploy peacekeepers, we include a dichotomous variable describing whether or not the outside state is a major power (the five permanent members of the UN Security Council are considered major powers for the period we study). To control for the effect of peacekeeping by international organizations, using data from the TPI dataset (Mullenbach, 2005) we include a dichotomous variable coded as 1 if there was a peacekeeping mission conducted by an international organization in the civil-war state in the previous year.

Because of the dyad-year unit of analysis and the rarity of peacekeeping conducted by states and ad-hoc coalitions, the vast majority of the observations in our data are observations of 'no peacekeeping'. We follow the guidance of King \& Zeng (2001) and estimate a rare events logit model using the ReLogit software program (Tomz, King \& Zeng, 2003) in Stata 11.0. Rare events logit provides a correction for the biased coefficients that are produced when a sample is skewed with very few positive values for a binary dependent variable. In our case, there is a very large number of observations of no peacekeeping and very few observations of peacekeeping. As King \& Zeng (2001) point out, there is hardly a downside to the use of rare events logit. If the bias produced by the sample is very large, rare events logit will outperform a logit model. If the bias is small, rare events logit will produce the same results as a logit model.

\section{Results}

Broadly speaking, the results of our analysis are consistent with much of the theoretical argument that we outlined above. We note some important differences from our expectations, particularly with respect to the impact of state interests and potential costs and risks on the propensity of states to engage in peacekeeping. Although peacekeepers are often criticized for selecting 'easy' cases, our findings challenge that conventional wisdom, instead suggesting that they are often drawn to conflicts that show the greatest need for intervention and those posing the greatest challenges. These results are summarized in Table I, with relative risks described in Table II. ${ }^{6}$

Consistent with much of the peacekeeping literature, major powers, due to their broad strategic interests and their high capacity for intervention, are $89 \%$ more likely to deploy peacekeepers to a civil war than non-major

\footnotetext{
${ }^{6}$ Because we employ a dyadic approach and because peacekeeping is a rare event, the risk of any individual state deploying peacekeepers during a civil-war year is quite small. In the aggregate, however, the significant factors that we explore in the model carry important effects for the occurrence of peacekeeping.
} 
Table I. Rare events logit analysis for the deployment of state peacekeeping

\begin{tabular}{|c|c|c|c|}
\hline Independent variables & All & $\begin{array}{l}\text { Major } \\
\text { power }\end{array}$ & $\begin{array}{c}\text { Non-major } \\
\text { power }\end{array}$ \\
\hline \multicolumn{4}{|l|}{ State Interests } \\
\hline \multirow[t]{2}{*}{ Largest religious or ethnic group in third party same as second largest in state } & $0.848^{* * *}$ & $1.436^{*}$ & $0.740^{*}$ \\
\hline & {$[0.262]$} & [0.603] & {$[0.322]$} \\
\hline \multirow[t]{2}{*}{ Largest religious or ethnic group same in state and third party } & 0.327 & 0.247 & 0.150 \\
\hline & {$[0.276]$} & {$[0.486]$} & {$[0.359]$} \\
\hline \multirow[t]{2}{*}{ Contiguous state } & -0.297 & & -0.256 \\
\hline & [1.363] & & {$[1.614]$} \\
\hline \multirow[t]{2}{*}{ Former colony } & 0.712 & -0.230 & $2.472^{* *}$ \\
\hline & {$[0.600]$} & {$[0.795]$} & {$[0.665]$} \\
\hline \multirow[t]{2}{*}{ Total trade (lagged, logged) } & $0.212^{* *}$ & 0.065 & $0.230^{* *}$ \\
\hline & {$[0.057]$} & [0.109] & {$[0.058]$} \\
\hline \multirow[t]{2}{*}{ Defense pact } & 0.232 & 0.478 & $0.781+$ \\
\hline & {$[0.470]$} & {$[1.001]$} & {$[0.512]$} \\
\hline \multicolumn{4}{|l|}{ Urgency for Intervention } \\
\hline \multirow[t]{2}{*}{ Cumulative battle deaths (logged) } & $0.198^{* *}$ & $0.514^{* *}$ & $0.130+$ \\
\hline & {$[0.075]$} & {$[0.189]$} & {$[0.080]$} \\
\hline \multirow[t]{2}{*}{ Elapsed civil war time (years) } & $0.015+$ & -0.0002 & $0.026^{*}$ \\
\hline & {$[0.010]$} & {$[0.015]$} & {$[0.012]$} \\
\hline \multirow[t]{2}{*}{ Genocide (lagged) } & -0.417 & -0.575 & -0.430 \\
\hline & {$[0.280]$} & {$[0.583]$} & {$[0.326]$} \\
\hline \multirow[t]{2}{*}{ Refugees (lagged, logged) } & $0.059^{* *}$ & 0.047 & $0.065^{* *}$ \\
\hline & {$[0.022]$} & {$[0.048]$} & {$[0.025]$} \\
\hline \multirow[t]{2}{*}{ Contiguous* Refugee interaction } & 0.069 & & 0.075 \\
\hline & [0.129] & & {$[0.153]$} \\
\hline \multicolumn{4}{|l|}{ Costs and Risks } \\
\hline \multirow[t]{2}{*}{ Ethnic conflict } & $0.982^{* *}$ & 0.638 & $1.228^{* *}$ \\
\hline & {$[0.287]$} & [0.519] & {$[0.357]$} \\
\hline \multirow{2}{*}{ Number of factions } & 0.026 & $0.123^{*}$ & 0.002 \\
\hline & {$[0.027]$} & {$[0.053]$} & {$[0.034]$} \\
\hline \multicolumn{4}{|l|}{ Opportunities } \\
\hline \multirow[t]{2}{*}{ Total number of previous mediation acceptances (lagged) } & $1.051^{* *}$ & $0.905^{* *}$ & $1.198^{* *}$ \\
\hline & {$[0.226]$} & {$[0.309]$} & {$[0.495]$} \\
\hline \multicolumn{4}{|l|}{ Controls } \\
\hline \multirow[t]{2}{*}{ IO peacekeepers (lagged) } & -0.468 & $0.992+$ & -1.572 \\
\hline & [0.429] & {$[0.560]$} & [1.034] \\
\hline \multirow[t]{2}{*}{ Third party is a major power } & $0.627+$ & & \\
\hline & {$[0.441]$} & & \\
\hline \multirow[t]{2}{*}{ Force ratio } & $-0.641^{* *}$ & -0.619 & $-0.642^{*}$ \\
\hline & {$[0.171]$} & {$[1.051]$} & {$[0.174]$} \\
\hline \multirow[t]{2}{*}{ Constant } & $-10.559^{\text {*k }}$ & $-12.101^{* *}$ & $-10.173^{*}$ \\
\hline & {$[0.882]$} & {$[2.566]$} & {$[0.913]$} \\
\hline Observations & 116,036 & 4,135 & 111,721 \\
\hline Number of state peacekeeping missions & 74 & 19 & 55 \\
\hline
\end{tabular}

Robust standard errors in brackets. + significant at $10 \% ;{ }^{*}$ significant at $5 \%$; ${ }^{* *}$ significant at $1 \%$.

powers. The USA, UK, France, and Russia each participated in several state-conducted peacekeeping missions in our sample. All four participated in the small Joint Verification Mission in Mozambique, 1990-1992; the USA, the UK, and France participated in 'Operation Restore Hope' in Somalia, 1992-1993, the International
Force for East Timor, 1999-2000, and the Multinational Force for Lebanon, 1982. The USA also intervened in Haiti and Rwanda, the UK in Zimbabwe, France in Rwanda, and Russia in Moldova, Georgia, and Tajikistan. Only China did not participate in any stateconducted peacekeeping missions. 
Table II. Relative risks for the deployment of state peacekeeping

\begin{tabular}{|c|c|c|c|c|}
\hline & Change & All & Major power & Non-major power \\
\hline \multicolumn{5}{|l|}{ State interests } \\
\hline $\begin{array}{l}\text { Largest religious or ethnic group in } \\
\text { third party same as second largest in state }\end{array}$ & 0 to 1 & 2.33 & 3.85 & 2.05 \\
\hline Former colony & 0 to 1 & & & 12.08 \\
\hline Total trade (lagged, logged) & 25 th to 75 th & 1.60 & & 1.57 \\
\hline Defense pact & 0 to 1 & & & 2.22 \\
\hline \multicolumn{5}{|l|}{ Urgency for intervention } \\
\hline Cumulative battle-deaths (logged) & 25 th to 75 th & 1.96 & 6.48 & 1.55 \\
\hline Elapsed civil war time (years) & 25 th to 75 th & 1.22 & & 1.40 \\
\hline Refugees, non-contiguous state (lagged, logged) & 25 th to 75 th & 1.79 & & 1.89 \\
\hline \multicolumn{5}{|l|}{ Costs and risks } \\
\hline Ethnic conflict & 0 to 1 & 2.64 & & 3.45 \\
\hline Number of factions & 25 th to 75 th & & 1.45 & \\
\hline \multicolumn{5}{|l|}{ Opportunities } \\
\hline Total number of previous mediation & 0 to 1 & 2.86 & 2.46 & 3.27 \\
\hline acceptances (lagged) & 1 to 4 & 22.71 & 13.95 & 37.00 \\
\hline \multicolumn{5}{|l|}{ Controls } \\
\hline IGO peacekeepers (lagged) & 0 to 1 & & 2.68 & \\
\hline Third party is a major power & 0 to 1 & 1.89 & & \\
\hline Force ratio & 25 th to 75 th & 0.24 & & 0.24 \\
\hline
\end{tabular}

Beyond the distinction between major powers and others, stronger third-party states are more likely to send peacekeepers on their own account. As the gap in relative capacity between a civil-war state and an outside state grows, the likelihood of peacekeeping by the outside state decreases. A state with half as many troops as a civil-war state is $36 \%$ less likely to participate in peacekeeping than a state with twice as many troops as the civil-war state. This effect is consistent with Mullenbach's (2005) finding that peacekeeping missions of any form are less likely to take place in conflicts involving a major power. As we note below, although major powers are more likely to engage in state-conducted peacekeeping, the factors that encourage state peacekeeping differ substantially between major and minor powers.

Because states act strategically and peacekeeping is a costly policy tool, we expected state interests to exert a powerful influence upon the choice of when and where states deploy peacekeepers. Our findings are consistent with this expectation: political, social, and economic ties each increase the likelihood of state peacekeeping.

Concern for ethnic kin in another state carries a powerful motivating effect for state peacekeeping. Interestingly, all ethnic ties are not created equal in terms of encouraging peacekeeping. An outside state whose majority ethnic group is the same as the second-largest ethnic group in a civil-war state (a majority-minority dyad) is more than twice as likely to deploy peacekeepers to a conflict as a state with no ethnic ties. This effect is particularly pronounced among major power states. A shared ethnic link increases the likelihood a major power will deploy peacekeepers by nearly a factor of four. Yet, a state sharing the same majority ethnic group as a civil-war state (a majority-majority dyad) is not significantly more likely to deploy peacekeepers.

These divergent findings with respect to ethnic ties suggest that states see a protective role for the peacekeepers they deploy. When a civil war represents a threat to a minority group with ethnic ties to an outside state, that state may see the importance of deploying peacekeepers to provide protection to their ethnic kin. Although a civil war may pose a threat to a linked majority group, this threat seems to be viewed as not being as acutely dangerous as that posed to a minority group. A state sharing the same majority as a civil-war state appears to see less urgency to deploy peacekeepers, perhaps using other means to support their ethnic kin.

Other types of interests encourage state-conducted peacekeeping. These interests differ substantially between major and non-major powers. State interests play a more direct role in guiding non-major powers' decisions about when to conduct peacekeeping. Trade ties, for example, significantly increase the likelihood of peacekeeping by a non-major power. Non-major power states are $57 \%$ more likely to provide peacekeeping to a country with which it has a high level of trade than one 
with which it has a low level of trade. Colonial and alliance ties also heighten the likelihood of peacekeeping by non-major powers. Among these states, peacekeepers are twelve times more likely to be deployed to a former colony than a non-colony. Peacekeeping by Portugal in Mozambique, Italy in Somalia, and Australia in Papua New Guinea drive this colonial effect. A non-major power is more than twice as likely to provide peacekeepers to a civil war involving a state with which it has a defense pact than one without such a strategic link, although this effect is only nominally significant. For major powers, direct state interests play a narrower role in determining whether they send peacekeepers on state-conducted missions. Only ethnic linkages between a major power state and a civil-war state significantly increase the likelihood that the state will engage in peacekeeping. This is mainly due to the fact that Christians are the second-largest religious group in several civil-war countries, such as Indonesia, in which the USA, the UK, and France have intervened. Trade ties, defense pacts, and colonial relationships do not significantly influence the likelihood of major-power peacekeeping. Why do state interests seem to drive non-major power peacekeeping decisions more than major power decisions? We can envision two potential explanations for this finding.

First, given the smaller pool of resources they have to work with, non-major powers may simply be forced to be more judicious in their application of peacekeeping, choosing interventions in which they have the most important interests at stake. Major powers, with a greater capacity to shape foreign affairs, may be better able to pay the costs of peacekeeping missions that are tangential to their most important interests. In this respect, because of their greater strength, major powers are better able to see the provision of peacekeeping as a public good provided to the international community.

Another possible explanation for this finding rests upon the differences in policy options available to major and non-major powers. While major powers can choose to protect their interests by providing peacekeeping either unilaterally or through an ad-hoc coalition of states, they also enjoy a substantial amount of influence over the international organizations most likely to provide peacekeeping. Non-major powers have less leverage over the decisions of international organizations. As a result, while a non-major power seeking to protect its interests in a civil-war state may have few options beyond leading a peacekeeping mission itself, major powers can also use their influence in international organizations like NATO and the United Nations to encourage them to provide peacekeeping in conflicts in which they have an interest.

For instance, Australia and New Zealand led four state-peacekeeping missions to Papua New Guinea's Bougainville region between 1994 and 2005, whereas the UN deployed one two-person observer mission. In contrast, UN peacekeeping missions immediately followed both US-led missions to Haiti. Indeed, we find a close link between major-power peacekeeping and international organization peacekeeping such that major powers are $268 \%$ more likely to deploy peacekeepers to conflicts in which an international organization has already sent peacekeepers.

We expected that geographic proximity to a civil war would create an important interest for states to provide peacekeeping. Surprisingly, contiguous states are not significantly more likely to deploy peacekeepers, even when the conflict produces large numbers of refugees. In fact, there are only five cases of contiguous peacekeeping in our dataset: Russia in Georgia 1992, Ukraine in Moldova 1992, Chad in the Central African Republic 1997. and Kyrgyzstan and Uzbekistan in Tajikistan 1993. One explanation for this null finding may rest with the interaction between the incentives that proximity creates for intervention and the costs that a civil war imposes upon neighboring states.

On one hand, a civil war certainly raises alarms among contiguous states as violence threatens to spill over into their territory, and they absorb costs from refugees, limitations on trade, and general regional instability. This alarm encourages neighboring states to consider their policy options to deal with the conflict, including the use of military force. On the other hand, the costs imposed upon neighboring states by civil wars may undermine the ability of neighboring states to respond by deploying peacekeepers. These costs are often borne by relatively weak neighboring states, as civil wars tend to cluster in space (Buhaug \& Gleditsch, 2008), flourishing in regions with low levels of economic development and unstable governments. This narrows the options of neighboring states to use military force. When neighboring states do intervene militarily, they often take sides, rather than by providing more neutral peacekeeping. For instance, Angola, Uganda, Rwanda, and Burundi intervened on either side in the war in the Congo, 1998-2003, while the UN, the EU, and the OAU under Algerian leadership sent peacekeepers.

The finding that state interests influence where state peacekeepers are deployed stands in contrast to the relationship between state interests and the deployment of UN peacekeepers observed in the literature. Jakobsen (1996) sees little link between state interests and the 
onset of UN peacekeeping missions. Similarly, Gilligan \& Stedman (2003) find no evidence of an increased propensity for UN peacekeeping missions to be deployed to former colonies. Evaluating our findings against this literature suggests that national interests shape both when states respond to civil wars and how they respond. The most important national interests that states seek to protect - defense pacts, ethnic linkages, former colonial ties, and trade - not only push states to respond with peacekeeping, but, particularly for non-major powers, also encourage them to provide the peacekeeping themselves rather than through an international organization.

Although state interests play an important role, they are not the only determinant of state peacekeeping. The urgency a conflict shows for peacekeeping strongly influences the likelihood of state-conducted peacekeeping. Our findings show that rather than avoiding the most difficult conflicts to manage, state peacekeeping is most likely to take place in the most challenging civil wars. A civil war with an accumulated 44,000 battle-deaths is $96 \%$ more likely to see state peacekeeping than a war with 100 battle-deaths. Major-power peacekeeping is especially driven by high mortality: a similar change from the 25 th percentile to the 75 th percentile of battle-deaths increases the likelihood for a major power to provide peacekeeping by $648 \%$, but only by $55 \%$ for minor powers.

Just as large numbers of battle-deaths signal the intensity of a conflict, the duration of a conflict points to its intractability. Here again, states take on the tougher cases, with peacekeepers being more likely to be deployed to longrunning civil wars. Peacekeeping by non-major powers becomes more likely as a conflict ages. The chances of a non-major power engaging in peacekeeping in a 17-year old civil war are $40 \%$ higher than in a 4 -year old conflict. Conflict duration, however, does not significantly influence the likelihood of major power peacekeeping.

Consistent with their tendency to deploy peacekeepers to long-running conflicts, non-major powers are also more likely to intervene in ethnic wars, among the most challenging conflicts for conflict management. A non-major power state is more than three times as likely to provide peacekeeping to an ethnic conflict as to a non-ethnic conflict. ${ }^{7}$ This finding runs counter to

\footnotetext{
7 Interestingly, this tendency of minor powers to provide peacekeeping to ethnic wars is independent of ethnic linkages between the two states. We included interaction terms in the model to test whether the combination of shared ethnic linkages and ethnic war increased the likelihood of peacekeeping. This term was not significant and did not improve the explanatory capacity of any of the models.
}

our expectations regarding the impact of perceived risk upon the likelihood for peacekeeping. Rather than deterring minor powers, ethnic conflicts instead convince them of the need for peacekeeping.

We see no such links between ethnic conflict, conflict duration, and major power peacekeeping. This is not to say that major powers avoid the most intractable conflicts. It is major powers that are significantly more likely to send peacekeepers to civil wars with multiple warring factions. Increasing the number of factions in a civil war from two to five increases the likelihood that a major power will deploy peacekeepers to the conflict by $45 \%$. Again, this finding is counter to our expectations. Major powers do not shrink from peacekeeping in the most difficult cases; they are more likely to intervene in them.

Major and non-major power peacekeeping differs most strongly in terms of the impact of civil-war refugees. Although we expected the combination of contiguity and refugees to raise the risk of peacekeeping, non-major powers contiguous to a civil war producing a large number of refugees are not significantly more likely to send peacekeepers as part of a state mission. For a non-major power that is not contiguous to a civil war, increasing the number of refugees produced by the conflict from 0 to nearly 24,000 increases the likelihood that the non-major power will deploy peacekeepers to the conflict by $89 \%$. We believe that the different effects of refugees upon contiguous and non-contiguous non-major powers reflect the differences in the costs that refugees impose.

While non-contiguous, non-major powers are likely to see a conflict producing a large number of refugees as evidence of a humanitarian emergency that requires intervention, because of their distance from the conflict, they are unlikely to bear the most direct costs from refugee flows. Contiguous, non-major powers, by contrast, not only see the humanitarian emergency that refugees indicate, but they also are substantially more likely to bear the costs produced by refugees. The costs nonmajor powers face include both those associated with protecting their territory from the instability that large refugee flows often bring and costs of providing relief assistance to the refugees. These costs, which come in addition to other economic costs from the war, further sap the capacity of these states to offer peacekeeping. This effect is similar to the general hesitation of contiguous countries to send peacekeepers, discussed above.

Major power peacekeeping does not appear to be significantly influenced by the presence of large numbers of refugees. While non-major power peacekeeping is influenced by the intensity of a conflict, its duration, and its impact upon civilians, major powers much more strongly 
focus upon the intensity of a conflict in deciding when and where to send peacekeepers. Despite these differences, we observe one commonality among major and non-major power peacekeeping - neither is more likely to take place in civil wars that result in genocide, those in most dire need of intervention.

Despite the fact that the threat of high costs does not dissuade states from engaging in civil-war peacekeeping, states do choose their interventions carefully. Participation by the warring parties in international mediation, by raising hope for an eventual settlement, heightens the willingness of states to provide peacekeeping. One mediation effort between civil war belligerents nearly triples the risk that states will provide peacekeepers to the conflict. Increasing the number of prior mediation efforts from one to four further increases the likelihood of peacekeeping by a factor of nearly 23 .

\section{Conclusion}

Peacekeeping missions deployed by states or ad-hoc coalitions of states are rare. Yet, the reasons states send their soldiers as peacekeepers to a civil war differ from those factors identified for peacekeeping missions by international organizations, in particular the United Nations. Not surprisingly, when acting outside international organizations, states are able to take their own interests more directly into account and select those civil wars to which they send peacekeepers accordingly. States' interests play a much greater role here than, for example, the interests of major powers with regard to UN peacekeeping. When states send peacekeepers they are more likely to choose former colonies, military allies, trade partners, or countries with which they have ethnic ties. Taking into consideration the high costs of peacekeeping, states - and in particular non-major powers - act when their interests are at stake and when they perceive an opportunity for success.

In addition to weighing the costs of peacekeeping with their own interests and opportunities for a successful mission, states also react to the urgency of a civil war. Similar to the UN and other international organizations, they are more likely to send peacekeepers to civil wars that cause widespread human suffering among civilians. Civil wars that cause high numbers of people to flee their country are more likely to attract state-conducted peacekeeping. States also do not shy away from the most protracted, complicated wars. Rather, they are more likely to send peacekeepers to long, ethnic wars with many fighting factions that kill many people. However, civil wars during which genocide is committed are not more likely to attract state peacekeeping.

The differences between the factors that signal the urgency for state peacekeeping by major and nonmajor powers that we see here are striking. Major power peacekeeping is strongly driven by conflicts that show the greatest capacity to spread, those producing the highest numbers of battle-deaths and involving a large number of warring parties. Minor power peacekeeping, while influenced less by the intensity of fighting, is more strongly encouraged by concern about consequences for civilians, encouraging them to intervene in longrunning, ethnically-rooted civil wars that produce large numbers of refugees. In this respect, both major and non-major powers choose tough cases for peacekeeping, intervening where it is needed the most. Yet, what determines urgency for state peacekeeping differs between major and non-major powers.

Taken together with what we already know on when and where UN peacekeeping missions are deployed, the findings in this study on the factors influencing stateconducted peacekeeping complete the picture of when third-party actors choose to intervene to manage a civil war. This study raises some important questions for future research. Although we have pointed to some forces that push states toward providing peacekeeping, we do not know the degree to which state peacekeeping occurs when it is likely to be successful. Peacekeeping can be a noble endeavor where third parties manage the most dangerous civil wars, but the poor track record of peacekeeping underscores the importance of identifying whether peacekeepers are deployed under 'winnable' conditions.

\section{Replication Data}

The statistical analyses described in this article were conducted using Stata 11.0. The dataset, do- and logfiles for the empirical analysis in this article can be found at http://www.prio.no/jpr/datasets.

\section{Acknowledgments}

We would like to thank our colleagues at the University of North Texas, at the conference of the Midwestern Political Science Association 2005, and the anonymous reviewers and editors of $J P R$ for their very helpful comments on earlier versions of this article. The views expressed in this paper are those of the authors and do not necessarily reflect those of the United Nations or OCHA. 


\section{References}

Andersson, Andreas (2000) Democracies and UN peacekeeping operations, 1990-1996. International Peacekeeping 7(2): 1-22.

Austvoll, Martin (2005) Transnational ethnic dimensions of third-party interventions in civil conflicts. MA thesis, Department of Political Science, University of Oslo.

Bennett, D Scott \& Allan C Stam (2000) EUGene: A conceptual manual. International Interactions 26(2): 179-204.

Bercovitch, Jacob (1997) Mediation in international conflict: Theory, practice and developments. In: I William Zartman \& J Lewis Rasmussen (eds) Peacemaking in International Conflict. Methods and Techniques. Washington, DC: United States Institute of Peace, 163-194.

Bercovitch, Jacob; Theodore J Anagnoson \& Donnette L Wille (1991) Some conceptual issues and empirical trends in the study of successful mediation in international relations. Journal of Peace Research 28(1): 7-17.

Buhaug, Halvard \& Kristian Skrede Gleditsch (2008) Contagion or confusion? Why conflicts cluster in space. International Studies Quarterly 52(2): 215-233.

Carment, David \& Dane Rowlands (1998) Three's company: Evaluating third-party intervention in intrastate conflict. Journal of Conflict Resolution 42(5): 572-599.

Davenport, Christian; Will Moore \& Steven C Poe (2003) Sometimes you just have to leave: Domestic threats and forced migration, 1964-1989. International Interactions 29(1): 27-55.

Davis, David R \& Will H Moore (1997) Ethnicity matters: Transnational ethnic alliances and foreign policy behavior. International Studies Quarterly 41(1): 171-184.

Donnelly, Jack (2003) Universal Human Rights in Theory and Practice. Ithaca, NY: Cornell University Press.

Dowty, Aland \& Gil Loescher (1996) Refugee flows as grounds for international action. International Security 21(1): 43-71.

Doyle, Michael \& Nicholas Sambanis (2000) International peacekeeping: A theoretical and quantitative analysis. American Political Science Review 94(4): 779-801.

Durch, William J (1993) Getting involved: The political-military context. In: William J Durch (ed.) The Evolution of UN Peacekeeping: Case Studies and Comparative Analysis. New York: St Martin's, 16-38.

Ellingsen, Tanja (2000) Colorful community or ethnic witches' brew? Multiethnicity and domestic conflict during and after the Cold War. Journal of Conflict Resolution 44(2): 228-249.

Evans, Gareth (2008) The Responsibility to Protect: Ending Mass Atrocity Crimes Once and For All. Washington, DC: Brookings Institution.

Fearon, James D \& David D Laitin (2003) Ethnicity, insurgency, and civil war. American Political Science Review 97(1): 75-90.

Feste, Karen A (1992) Expanding the Frontiers: Superpower Intervention in the Cold War. New York: Praeger.

Finnemore, Martha (2004) Constructing norms of humanitarian intervention. In: Karen A Mingst \& Jack L Snyder (eds) Essential Readings in World Politics, 2nd edn. New York: WW Norton, 102-118.

Fortna, Virginia (2004a) Peace Time: Cease-Fire Agreements and the Durability of Peace. Princeton, NJ: Princeton University Press.

Fortna, Virginia (2004b) Does peacekeeping keep peace? International intervention and the duration of peace after civil war. International Studies Quarterly 48(2): 269-292.

Ghobarah, Hazem A; Paul Huth \& Bruce Russett (2003) Civil wars kill and maim people - long after the shooting stops. American Political Science Review 97(2): 189-202.

Gibler, Douglas M \& Meredith Reid Sarkees (2004) Measuring alliances: The correlates of war formal interstate alliance dataset, 1816-2000. Journal of Peace Research 41(2): 211-222.

Gilligan, Michael J \& Stephen Stedman (2003) Where do peacekeepers go? International Studies Review 5(1): 37-54.

Gleditsch, Kristian S (2002) Expanded trade and GDP data. Journal of Conflict Resolution 46(5): 712-724.

Gleditsch, Kristian S (2007) Transnational dimensions of civil war. Journal of Peace Research 44(3): 293-310.

Gochman, Charles (1991) Interstate metrics: Conceptualizing, operationalizing, and measuring geographic proximity of states since the Congress of Vienna. International Interactions 17(1): 93-112.

Harff, Barbara (2003) No lessons learned from the Holocaust? Assessing risks of genocide and political mass murder since 1955. American Political Science Review 97(1): 57-73.

Hartzell, Caroline A; Matthew Hoddie \& Donald Rothchild (2001) Stabilizing the peace after civil war. International Organization 55(1): 183-208.

Hensel, Paul (2006) ICOW Colonial History dataset (http://garnet.acns.fsu.edu/ phensel/Data/colhist. zip, accessed 12 March 2009). 
Jakobsen, Peter Viggo (1996) National interest, humanitarianism or CNN: What triggers UN peace enforcement after the Cold War? Journal of Peace Research 33(2): 205-215.

King, Gary \& Langche Zeng (2001) Explaining rare events in international relations. International Organization 55(3): 693-715.

Krain, Matthew (1997) State-sponsored mass murder: The onset and severity of genocides and politicides. Journal of Conflict Resolution 41(3): 331-360.

Krain, Matthew (2005) International intervention and the severity of genocides and politicides. International Studies Quarterly 49(3): 363-388.

Kressel, Kenneth \& Dean G Pruitt, eds (1989) Mediation Research, The Process and Effectiveness of ThirdParty Intervention. San Francisco, CA: Jossey-Bass.

Lacina, Bethany \& Nils Petter Gleditsch (2005) Monitoring trends in global combat: A new dataset of battle deaths. European Journal of Population 21(2-3): 145-166.

Moore, Will H \& Stephen M Shellman (2004) Fear of persecution: Forced migration, 1952-1995. Journal of Conflict Resolution 40(5): 723-745.

Morgenthau, Hans J (1967) To intervene or not to intervene. Foreign Affairs 45(3): 425-436.

Most, Benjamin A \& Harvey Starr (1989) Inquiry, Logic and International Politics. Columbia, SC: University of South Carolina Press.

Mueller, John E (2003) Policing the remnants of war. Journal of Peace Research 40(3): 507-518.

Mullenbach, Mark (2005) Deciding to keep peace: An analysis of international influences on the establishment of third-party peacekeeping missions. International Studies Quarterly 49(3): 529-556.

Petersen, Karen K (2004) A research note: Reexamining transnational ethnic alliances and foreign policy behavior. International Interactions 30(1): 25-42.

Ponzio, Richard (2005) The Solomon Islands: The UN and intervention by coalitions of the willing. International Peacekeeping 12(2): 173-188.

Regan, Patrick (1998) Choosing to intervene: Outside interventions in internal conflicts. Journal of Politics 60(3): 754-779.

Regan, Patrick \& Allan C Stam (2000) In the nick of time: Conflict management, mediation timing, and the duration of interstate disputes. International Studies Quarterly 44(2): 239-260.

Regan, Patrick; Richard W Frank \& Aysegul Aydin (2009) Diplomatic interventions and civil war: A new dataset. Journal of Peace Research 46(1): 135-146.
Saideman, Sabine (1997) Explaining the international relations of secessionist conflicts: Vulnerability versus ethnic ties. International Organization 51(4): 721-753.

Saideman, Sabine (2002) Discrimination in international relations: Examining why some ethnic groups receive more external support than others. Joumal of Peace Research 39(1): 27-50.

Sambanis, Nicholas \& Jonah Schulhofer-Wohl (2005) Evaluating multilateral interventions in civil wars: A comparison of UN and non-UN peace operations. In: Dimitris Bourantonis, Kostas Ifantis \& Panayotis Tsakonas (eds) Multilateralism and Security in an Era of Globalization. New York: Routledge, 252-287.

Schmeidl, Sabine (1997) Exploring the causes of forced migration: A pooled time-series analysis, 1971-1990. Social Science Quarterly 78(2): 284-308.

Singer, J David \& Melvin Small (1982) Resort to Arms: International and Civil War, 1816-1980. Beverly Hills, CA: Sage.

Singer, J David; Stuart Bremer \& John Stuckey (1972) Capability distribution, uncertainty, and war, 18201965. In: Bruce Russett (ed.) Peace, War and Numbers. Beverly Hills, CA: Sage, 19-48.

Siverson, Randolph M \& Harvey Starr (1992) The Diffusion of War. Ann Arbor, MI: University of Michigan Press.

Tomz, Michael; Gary King \& Langche Zeng (2003) ReLogit: Rare events logistic regression. Journal of Statistical Software 8(2) (www.jstatsoft.org/v08/i02).

Vasquez, John A (1993) The War Puzzle. Cambridge: Cambridge University Press.

Vasquez, John A (1995) Why do neighbors fight? Proximity, interaction or territoriality. Journal of Peace Research 32(3): 277-293.

Weil, Carola (2001) The protection-neutrality dilemma in humanitarian emergencies: Why the need for military intervention? International Migration Review 35(1): 79-116.

NICOLAS ROST, b. 1980, MSc Political Science (University of North Texas, 2005), MA Politics and Management (University of Konstanz, 2006); Common Humanitarian Fund/Donor Relations Officer at the United Nations Office for the Coordination of Humanitarian Affairs for Somalia (2009-).

J MICHAEL GREIG, b. 1971, PhD in Political Science (University of Illinois at Urbana-Champaign, 2002); Associate Professor, University of North Texas (2002- ); current research interests: conflict management, imposed polities. 